\title{
What is the Effect of a Support Program for Female Family Caregivers of Dementia on Depression? ${ }^{1}$
}

\author{
Hyoshin Kim \\ Dept. of Nursing, Chungwoon University, \\ San29, Namjang-ri, Hongseong-eup, Hongseong-gun, Chungnam, 350-701, \\ Republic of Korea \\ Dept. of Nursing, Yong-In Songdam College, \\ 571-1 Mapyeong-dong, Cheoin-gu Yongin-si, Gyeonggi-do, 449-710, \\ Republic of Korea \\ hyoshin@ysc.ac.kr
}

\begin{abstract}
This study attempts to measure the effect on depression of support programs for female family caregivers of dementia patients. Subjects are female family caregivers of dementia patients in Seoul and Gyeonggi-do. A total of 54 women were studied, with an experimental group of 28 and a control group of 26. Through the interview with female family caregivers of dementia patients, a review of the literature, and the participation of specialists, a support program fitting the Korean situation was developed, which the experimental group underwent through a total of 8 sessions for 2-3 hours a day once a week. No special intervention was given to the control group. Depression of the experimental group and the control group was measured through before and after the test. Depression change between the experimental group and control group was analyzed with t-test. The research found that depression of female family caregivers of dementia patients became significantly lowered in the experimental group compared with the control group after the support program. Hence, the support program for female family caregivers of dementia patients was verified as a safe and effective program for lowering depression in female family caregivers.
\end{abstract}

Keywords: Dementia, Female Family Caregiver, Depression

\section{Introduction}

\subsection{Necessity}

Korea is aging at a rate that is almost unsurpassed worldwide. Among Korean senior citizens over 65 years old, the number suffering dementia is assumed to already exceed 400,000 , and is expected to increase by about 2 times to 770,000 people by 2020[1]. Measures at the government level to find, cure, and take care of the rapidly increasing number of senior citizens with dementia are progressing, but most elderly dementia patients are still being taken care of at the level of their family. According to a National Study on the Prevalence of Dementia in Korean Elders, 9 out of 10 people taking care of elderly dementia patients were family members. Three out of four people taking care of elderly dementia patients experience severe mental, economic, and physical burdens, and in particular, many experience depression [1].

${ }^{1}$ This study was supported by an Academic Research Fund of Chungwoon University in 2013 
Female caregivers of elderly dementia patients who experience depression have high vulnerability to stress, experience decreased self-esteem and increased despair, and in severe cases, contemplate suicide [2]. Considering that Korea already has one of the highest suicide rates among OECD nations [3], suicide prevention and depression management must be taken seriously.

Family caregivers of dementia patients experience depression at least once in their life cycle, and are reported to be diagnosed with either depression or anxiety disorder at a rate 2-3 times higher than the general public [4]. In particular, Korean family caregivers have more serious depression compared with American family caregivers [5].

Amirkhanyan and Wolf [6] reported that taking care of elderly dementia patients decreased life satisfaction and increased depression, therefore reducing quality of life.

A comparison study of family caregivers of dementia patients in Korea and America found that caring for elderly dementia patients brings a heavy burden to family caregivers and causes depression or reduced life satisfaction. These findings appeared to span cultural differences, leading researchers to conclude that taking care of elderly dementia patients is a heavy burden around the world [7].

Caregivers of dementia patients lose interest in work or life due to the burden and stress, lose hope, consider themselves worthless, and show depression symptoms. Also, the frequent problematic behaviors and low social support for the elderly with dementia increase the burden and depression of caregivers [8].

Depression symptoms are influenced by degree of dementia being experienced by the elderly patient and the family caregivers' general characteristics and cultural characteristics. When the patient is severely demented, or if care support should be given in a large amount due to difficulty in daily living ability, lack of economic resources, a high time requirement, or decrease of caregiver's capability, it is reported that those factors are related to depression. Daily living ability of the demented elderly affects caregivers' depression. As the difficulty in the daily living of the demented elderly increases, the care time increases, which increases caregivers' depression due to a lack of time to take care of themselves and social isolation [8, 9]. Main caregivers taking care of dementia patients for more than 10 hours per day exhibited behavior symptoms, lack of daily living ability, and economic problems as factors of the care burden and due to such factors, caregivers became isolated from society, and exhibited negative wellbeing factors such as difficulty in relationships, fatigue, and so on[10].

To solve these problems, there are some interventions that can satisfy the demands of family caregivers of dementia patients [11]. The necessity of an intervention strategy using education on dementia, personal and group support, etc. to solve depression has been reported [8].

In Korea, daughters-in-law, spouses, and daughters, etc. are typically the ones taking care of the senior with dementia, and so female caregivers have a greater burden than male caregivers [1, 8]. Despite this, there has been little research in Korea comparing the effect on depression of support programs for female family caregivers of dementia, and the existing research has involved small numbers of subjects.

Therefore, in this study, unlike existing researches, female family caregivers of dementia were interviewed, a support program was developed, and effects of the support program on the depression of female family caregivers taking care of the demented elderly were analyzed by increasing the number of subjects, with the aim of proving the effects on depression among female family caregivers. 


\subsection{Purpose of the Study}

The purpose of the study is to prove the effects of a support program on depression in the female family caregivers by applying the support program for female family caregivers taking care of elderly dementia patients.

\section{Methodology}

\subsection{Design}

The study is a quasi-experimental study to verify the effects of the support program for female family caregivers on depression. The independent variable is the support program and the dependent variable is depression of female family caregivers taking care of the elderly dementia patients. The support program was developed by interviewing 54 female family caregivers, performing a review of the literature, and referring to the writer's experience and the participation of the specialists group. The support program was carried out in a total of 8 parts for $2-3$ hours a day once a week.

\subsection{Subject}

Experimental group subjects of this study agreed to participate in the support program as female family caregivers and completed the 8-week support program, and completed questionnaires before and after the experiment. The control group subjects of this study also agreed to participate as female family caregivers of dementia patients and completed questionnaires before and after the experiment.

\subsection{Instruments}

The instrument used to assess depression in this study was the Korean CES-D (Center for Epidemiologic Studies Depression Index) standardized by Cho Meng Je and Kim Gae Hee [12]. It indicates the subject's experiences for the past week in the areas of behavior, body, and recognition for a total of 20 symptoms, using a 4-score Likert scale, with a higher score meaning higher depression. This study showed Cronbach's $\alpha=.90$ in the pretest of instrument reliability and Cronbach's $\alpha=.89$ in the posttest.

\subsection{Resource Collection Method and Research Procedure}

Subjects of this study were collected with the cooperation of the administrators of nursing and welfare facilities for the elderly in Seoul, including dementia support centers, elderly welfare centers, domiciliary care facilities, advertisements on the internet and handout leaflets. Program contents were composed by reviewing the preceding literature and interviewing 54 female family caregivers taking care of the elderly dementia patients. After that, the support program was completed after receiving advice from a specialist group composed of a professor of elderly nursing, a professor of physical education, a director of an elderly care facility and a nurse of an elderly facility.

Afterwards, for the 28 subjects in the experimental group, the program proceeded through a total of 8 sessions, 2-3 hours a day and once a week for 8 weeks. Pretest questionnaires were completed through a preliminary meeting by both the experimental and control group. But the program proceeded with 8 sessions for the experimental group only. The program was not conducted on 26 subjects in the control group. After the support program, posttest questionnaires were completed by both the experimental and the control group. About a year was spent from collecting research subjects to finishing questionnaires. 
Table 1. Contents of Support Program for Female Family Caregivers Taking Care of the Demented Elderly

\begin{tabular}{|c|c|c|c|}
\hline Section & Theme & Details & Method \\
\hline $\begin{array}{l}\text { Preliminary } \\
\text { meeting }\end{array}$ & Orientation & $\begin{array}{l}\text {-Program overview } \\
\text {-Completing pretest } \\
\text { questionnaires }\end{array}$ & $\begin{array}{l}\text { - Overall explanation on the program and } \\
\text { questions and answers } \\
\text { - Informed consent to the research } \\
\text { - Completing pretest questionnaires consisting of } \\
20 \text { questions on depression }\end{array}$ \\
\hline 1 & $\begin{array}{c}\text { Understanding demented } \\
\text { patients }\end{array}$ & $\begin{array}{l}\text { - Dementia symptoms and } \\
\text { progress } \\
\text {-Common disease } \\
\text {-Home care method }\end{array}$ & $\begin{array}{l}\text { - Self-introduction } \\
\text { - Handout distribution } \\
\text {-Lecture } \\
\text {-Questions and answers }\end{array}$ \\
\hline 2 & Health management & $\begin{array}{l}\text { - Necessity of exercise } \\
\text { method, effectiveness, } \\
\text { precautions, etc. } \\
\text {-Method of nutrient } \\
\text { management }\end{array}$ & $\begin{array}{l}\text { - Handout distribution } \\
\text { - Lecture } \\
\text { - Questions and answers } \\
\text { - Sharing opinions }\end{array}$ \\
\hline 3 & Stress management & $\begin{array}{l}\text { - Stress and burden of taking } \\
\text { care of demented elderly } \\
\text { - Stress releasing method } \\
\text { - Establishing stress } \\
\text { management plan }\end{array}$ & $\begin{array}{l}\text { - Finding individual method of reducing } \\
\text { stress and depression } \\
\text { - Sharing individual experiences }\end{array}$ \\
\hline 4 & $\begin{array}{l}\text { Family conflict } \\
\text { resolution }\end{array}$ & $\begin{array}{l}\text { - Share difficulties of family } \\
\text { problem. } \\
\text { - Appropriately distribute } \\
\text { family members' roles in } \\
\text { taking care of the } \\
\text { demented elderly } \\
\text { - Find a direction for } \\
\text { problem-solving with } \\
\text { family }\end{array}$ & $\begin{array}{l}\text { - Share opinions with experimental subjects. } \\
\text { - Seek method of improving relationships } \\
\text { with the elderly dementia patient. } \\
\text { - Seek a method of reducing family conflicts and } \\
\text { depression for each person. }\end{array}$ \\
\hline 5 & $\begin{array}{c}\text { Communication with the } \\
\text { demented elderly and } \\
\text { finding coping strategies }\end{array}$ & $\begin{array}{l}\text {-Proper communication with } \\
\text { the elderly dementia } \\
\text { patient } \\
\text { - Finding coping measures } \\
\text { for problematic behaviors } \\
\text { - Establish management } \\
\text { strategy. }\end{array}$ & $\begin{array}{l}\text { - Share methods of communicating with the } \\
\text { demented elderly. } \\
\text { - Share measures for problematic behaviors } \\
\text { - Share coping strategies in individual } \\
\text { situation } \\
\text { - Share means of releasing depression and } \\
\text { mental support }\end{array}$ \\
\hline 6 & Art therapy & $\begin{array}{l}\text { - Art therapy for female } \\
\text { family caregivers }\end{array}$ & $\begin{array}{l}\text { - Make a collage on what you want to } \\
\text { discard and what you want to keep under the } \\
\text { supervision of art therapist. } \\
\text { - Make a grain mandala using clay, grains } \\
\text { (black bean, kidney bean, pumpkin seed, } \\
\text { adzuki bean, sorghum, black rice, millet, } \\
\text { etc.), and silver foil plate. }\end{array}$ \\
\hline 7 & $\begin{array}{l}\text { Laughter therapy } \\
\text { Recreation }\end{array}$ & $\begin{array}{l}\text { - Laughter therapy for } \\
\text { female family caregivers } \\
\text { - Recreation therapy for } \\
\text { female family caregivers }\end{array}$ & $\begin{array}{l}\text { - Laugh loudly and shout to expel stress at } \\
\text { the instruction of the laughter therapist. } \\
\text { - Engage in recreation. }\end{array}$ \\
\hline 8 & $\begin{array}{l}\text { Provide local social } \\
\text { support and finishing }\end{array}$ & $\begin{array}{l}\text { - Provide information of } \\
\text { social support network } \\
\text { - Complete posttest } \\
\text { questionnaires }\end{array}$ & $\begin{array}{l}\text { - Provide information on local dementia } \\
\text { support centers, etc. } \\
\text { - Complete posttest questionnaire with } 20 \\
\text { questions on depression. } \\
\text { - Refreshments with experimental subjects and } \\
\text { finishing }\end{array}$ \\
\hline
\end{tabular}




\subsection{Resource Analysis}

Data was analyzed from a total of 54 people. Collected data were analyzed using SPSS Win 18.0.

(1) General characteristics and homogeneity analysis of female family caregivers taking care of the demented elderly were analyzed with percentage and $\chi 2$-test.

(2) Depression of female family caregivers before and after the experiment were analyzed with average, standard deviation and t-test. Significant level for the statistical significance was $\mathrm{p}<0.05$.

\section{Research Result}

\subsection{Homogeneity Test}

\subsubsection{General Characteristics and Homogeneity Test of Female Family Caregivers of Seniors with Dementia}

The results of the general characteristics and homogeneity test of female family caregivers taking care of the elderly dementia patients are as shown in Table 2.

General characteristics of the experimental group and the control group showed no differences, and the two groups were homogeneous.

Table 2. Homogeneity Test of Subjects ( $N=54)$

\begin{tabular}{|c|c|c|c|c|c|c|}
\hline $\begin{array}{l}\text { General } \\
\text { characteristics }\end{array}$ & Categories & $\begin{array}{l}\text { Exp. } \\
\text { N (\%) }\end{array}$ & $\begin{array}{l}\text { Cont. } \\
\text { N (\%) }\end{array}$ & $\begin{array}{l}\text { Total } \\
\text { N (\%) }\end{array}$ & $\chi^{2}$ & $\mathbf{p}$ \\
\hline Gender & Female & $28(100.00)$ & $26(100.00)$ & $54(100.00)$ & - & - \\
\hline \multirow[t]{6}{*}{ Age(yr) } & Below 40 & $2(7.14)$ & $0(0.00)$ & $2(3.70)$ & \multirow{6}{*}{10.797} & \multirow{6}{*}{0.056} \\
\hline & $40-49$ & $5(17.86)$ & $3(11.54)$ & $8(14.81)$ & & \\
\hline & $50-59$ & $12(42.86)$ & $5(19.23)$ & $17(31.48)$ & & \\
\hline & $60-69$ & $8(28.57)$ & $11(42.31)$ & 19(35.19) & & \\
\hline & $70-79$ & $0(0.00)$ & $4(15.38)$ & $4(7.41)$ & & \\
\hline & 80 and above & $1(3.57)$ & $3(11.54)$ & $4(7.41)$ & & \\
\hline \multirow[t]{2}{*}{ Residence } & Seoul & $22(78.57)$ & 25(96.15) & $47(87.04)$ & \multirow{2}{*}{3.694} & \multirow{2}{*}{0.102} \\
\hline & Gyunggi & $6(21.43)$ & 1(3.85) & 7(12.96) & & \\
\hline \multirow[t]{2}{*}{ Marital status } & Unmarried & $4(14.29)$ & 2(7.69) & $6(11.11)$ & \multirow{2}{*}{0.593} & \multirow{2}{*}{0.670} \\
\hline & Married & $24(85.71)$ & 24(92.31) & 48(88.89) & & \\
\hline \multirow[t]{2}{*}{$\begin{array}{l}\text { Number of family } \\
\text { members }\end{array}$} & 1 & $4(14.29)$ & $10(38.46)$ & $14(25.93)$ & \multirow{4}{*}{5.229} & \multirow{4}{*}{0.080} \\
\hline & & & & & & \\
\hline \multirow[t]{2}{*}{ (living together) } & $2-4$ & $20(71.43)$ & $11(42.31)$ & $31(57.41)$ & & \\
\hline & $5-6$ & $4(14.29)$ & $5(19.23)$ & $9(16.67)$ & & \\
\hline \multirow[t]{3}{*}{ Number of children } & 0 & $4(14.29)$ & $3(11.54)$ & $7(12.96)$ & \multirow{3}{*}{0.092} & \multirow{3}{*}{0.955} \\
\hline & $1-3$ & $22(78.57)$ & 21(80.77) & 43(79.63) & & \\
\hline & 4 or more & $2(7.14)$ & 2(7.69) & $4(7.41)$ & & \\
\hline \multirow[t]{2}{*}{ Religion } & Observant & $23(82.14)$ & 21(80.77) & $44(81.48)$ & 0017 & 0.897 \\
\hline & Not observant & $5(17.86)$ & $5(19.23)$ & 10(18.52) & & \\
\hline
\end{tabular}




\begin{tabular}{|c|c|c|c|c|c|c|}
\hline \multirow[t]{2}{*}{ Occupation } & Employed & $9(32.14)$ & $4(15.38)$ & $13(24.07)$ & \multirow{2}{*}{2.071} & \multirow{2}{*}{0.150} \\
\hline & Not employed & 19(67.86) & $22(84.62)$ & 41(75.93) & & \\
\hline \multirow{4}{*}{$\begin{array}{l}\text { Relationship with t } \\
\text { elderly dementia } \\
\text { patient }\end{array}$} & Daughter-in-law & $10(35.71)$ & $6(23.08)$ & 16(29.63) & \multirow{4}{*}{4.783} & \multirow{4}{*}{0.286} \\
\hline & Spouse & $10(35.71)$ & $6(23.08)$ & $16(29.63)$ & & \\
\hline & Daughter & $5(17.86)$ & 11(42.31) & 16(29.63) & & \\
\hline & Sister & $3(10.71)$ & $3(11.54)$ & $6(11.11)$ & & \\
\hline \multirow[t]{2}{*}{$\begin{array}{l}\text { Does the caregiver } \\
\text { have symptoms? }\end{array}$} & Yes & $24(85.71)$ & 24(92.31) & 48(88.89) & \multirow[t]{2}{*}{0.593} & \multirow[t]{2}{*}{0.670} \\
\hline & No & $4(14.29)$ & $2(7.69)$ & $6(11.11)$ & & \\
\hline
\end{tabular}

\subsubsection{Depression Change of Female Family Caregivers Taking Care of the Demented Elderly}

For depression of female family caregivers taking care of the demented elderly, significant differences between the experimental group and the control group were shown after applying the support program. The depression of the experimental group was significantly reduced compared with the control group after the support program (Table 3).

Table 3. Depression Before and After Support Program in the Experimental and Control Groups ( $N=54)$

\begin{tabular}{|c|c|c|c|c|c|c|c|}
\hline & Before & After & $\mathrm{t}$ & $\mathrm{p}$ & $\begin{array}{l}\text { Difference } \\
\text { (After-Before) }\end{array}$ & $\mathrm{t}$ & $\mathrm{p}$ \\
\hline \multicolumn{8}{|c|}{ Depression } \\
\hline Exp. & $2.08 \pm 0.55$ & $1.97 \pm 0.39$ & 1.12 & 0.274 & $0.11 \pm 0.52$ & \multirow{2}{*}{4.22} & \multirow{2}{*}{0.045} \\
\hline Cont. & $2.40 \pm 0.58$ & $2.36 \pm 0.58$ & 0.37 & 0.714 & $0.04 \pm 0.51$ & & \\
\hline
\end{tabular}

Exp. : Experimental group $(\mathrm{n}=28)$

Cont. : Control group ( $\mathrm{n}=24)$

Data represents mean \pm S.D.

\section{Discussion}

Depression is an emotional disturbance appearing as sadness or gloominess, and is on the continuous line from the normal emotion change to pathological state. Physiological symptoms include fatigue, loss of appetite, weight loss, and sleep disturbance [13].

Dementia proceeds chronically after its initial occurrence and leads to a slow degeneration. As dementia patients cause great difficulties to their families, it is known that family members of elderly dementia patients are subject to a serious mental, physical, and economic burden [6-8].

Despite the importance of services for families of elderly dementia patients, both for the family as well as for the patient, there are few such services available in Korea. As such, social support services that can reduce the family's burden and give continuous help are seriously required. Of the factors reducing the care burden of family caregivers taking care of elderly dementia patients, the importance of support has been proven in advanced research. Improving personal psychological adjustment and promoting-problem solving ability through the support significantly affects improvements in wellbeing [14]. 
The support program for female family caregivers taking care of elderly dementia patients in this study is a program developed to reduce depression among family caregivers through informative emotional support and coping ability improvement for female family caregivers.

The study found that depression was reduced significantly in the experimental group compared to the control group after the support program. Similar to the results that in the results of conducting support program for the demented elderly and family, the quality of life in the group program showed significant difference [11]. Also, it is similar to the results with the group consulting program of cognitive behavior to reduce care burden, depression, and anxiety of main caregivers taking care of the demented elderly, main caregivers' burden, depression, and anxiety all were reduced significantly in the posttest [14].

Also, the results of this study are similar to the results of a weekend short-term protection program for elderly dementia patients, which helped to reduce family caregivers' depression [15]. The results of this study are similar to the results of other research showing that experimental group had decreased stress and depression compared with the control group in the group program to empower caregivers taking care of the demented elderly to relieve negative emotions and have positive effects on personal capability[16].

The quality of care for elderly dementia patients depends on the care capability, especially of the main family caregivers. Dementia care is very difficult for family members lacking special knowledge and experience, and thus proper family support is required. Families of elderly dementia patients have diverse demands, such as demand on care method, demand related to treatment for the demented elderly, demand related to welfare, emotional support, and so on. In the review of previous research, an intervention for the family of an elderly dementia patient can satisfy the demands of family caregivers taking care of the demented elderly and bring a supportive interaction effect [11]. There are so few advanced articles about support programs for female caregivers of elderly dementia patients, but as support programs can reduce stress hormones of caregivers of demented elderly [17], it is assumed that support programs can reduce stress as well as depression.

Therefore, in this study it was found that the application of a support program for female caregivers for elderly dementia patients can reduce depression significantly, and it is assumed that this releases and expresses inherent emotions, and relieves negative emotions, giving positive effects to family caregivers.

In conclusion, when a support program is applied for female family caregivers taking care of elderly dementia patients, it is expected to have the positive effect of reducing depression among female family caregivers.

\section{References}

[1] Ministry of Health and Welfare, Seoul National University Hospital, National Study on the Prevalence of Dementia in Korean Elders http://www.mw.go.kr, (2008).

[2] H. Y. Kim, "A study on the relationship between suicidal ideation, schema, family cohesion-adaptibility and stress vulnerability”, Master’s thesis, Sungshin Women’s University, Korea, (2006).

[3] World Health Organization (WHO). WHO country reports and charts for suicide rates, http://www.who.int/mental_health/prevention/suicide/country_reports/en, (2011) January 01.

[4] L. K. Wright, E. C. Clipp and L. K. George, "Health consequences of caregiver stress", Medicine, Exercise, Nutrition and Health, vol. 2, (1993), pp. 181-191.

[5] G. Youn, B. G. Knight, H. S. Jeong and D. Benton, "Differences in familism values and caregiving outcomes among Korean, Korean American, and White American dementia caregivers”, Psychology of Aging, vol. 14, no. 3, (1999), pp. 355-364.

[6] A. Amirkhanyan and D. Wolf, "Caregiver stress and noncaregiver stress: exploring the pathways of psychiatric mobility”, The Gerongologist, vol. 43, no. 6, (2003), pp. 817-827. 
[7] S. Y. Kim, H. S. Yoon, J. S. Kim and W. E. Haley, "Factors Affecting Life Satisfaction and Depression of Caregivers of the Elderly with Dementia: A Comparative Study of Korean and American Caregivers”, The Korean Gerontological Society, vol. 23, no. 3, (2003), pp. 193-221.

[8] K. H. Sung, "Burden and depression of caregivers according to cognitive function and daily living ability of dementia patients”, Master’s Thesis of Ewha Womans University, (2006).

[9] J. Y. Cha, "A Study on the Effect of Group Art Therapy on Improving the Care Burden and Stress and Depression of the Primary Caregivers of Dementia Patients”, Master's Thesis of Soonchunhyang University, (2010).

[10] B. Roger, “The needs of caregiver in the long-term treatment of Alzheimer disease”, Alzheimer Association Disorder, vol. 18, no. 1, (2004), pp. 17-23.

[11] J. J. Oh, "A Comparative Study on the Effects of an Individual Intervention Program and a Group Intervention Program on the Demented Elderly and Their Families”, Journal of Korean Academy of Community Health Nursing, vol. 19, no. 2, (2008), pp. 205-215.

[12] M. J. Cho and K. H. Kim, "Diagnostic validity of the CES-D(Korean version) in the assessment of DSM-IIIR major depression”, Journal of the Korean Neuropsychiatric Association, vol. 32, no. 3, (1993).

[13] V. Vaccarino, S. V. Kasl, J. Abramson and H. M. Krumholz, "Depressive symptoms and risk of functional decline and death in patients with heart failure”, Journal of the American College of Cardiology, http://dx.doi.org/10.1016/S0735-1097(01)01334-1, vol. 38, no. 1, (2001), pp. 199-205.

[14] E. H. Lee and G. H. Youn, "Development of a Cognitive-Behavioral Group Intervention Program in Reducing 700sychological Distress for the Primary Caregivers of the Demented Elderly Persons”, Korean journal of research in gerontology, vol. 14, (2005), pp. 5-19.

[15] S. J. Lee, "Effectiveness of relief to the burden of Family Caregiver with senile Dementia Patients through short term care on a weekend caused by execution of 5 days system”, Master's Thesis of Silla University, (2004).

[16] H. S. Han, “The Development and Its Effectiveness of the Group Program on Empowerment for the Senile Dementia Caregivers”, Master’s Thesis of Honam University, (2004).

[17] H. Kim, "The effect of stress hormones for family caregivers of dementia on stress hormones", Communications in Computer and Information Science, http://dx.doi.org/10.1007/978-3-642-27180-9_34, vol. 261, (2011), pp. 278-285.

\section{Author}

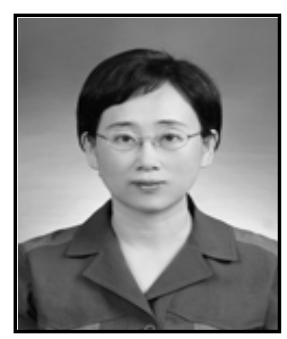

\section{Hyoshin Kim}

-February 1989: Dept of Nursing, Graduate School of Seoul National University (Master of Nursing)

-August 2000: Ph. D. Graduate School of Catholic University (Ph. D. of Nursing)

-March 2010-August 2013: Assistant Professor in the Dept. of Nursing of Chungwoon University

-August 2013-present: Assistant Professor in the Dept. of Nursing of Yongin Songdam College 